\title{
ERRATUM
}

Catherine B. Lewis-Kenedi • Rebecca A. Lange •

Chris M. Hall • Hugo Delgado-Granados

\section{The eruptive history of the Tequila volcanic field, western Mexico: ages, volumes, and relative proportions of lava types}

Published online: 21 June 2005

(C) Springer-Verlag 2005

\section{Bull Volcanol (2005) 67:391-414}

Tables $1 \mathrm{~b}, 1 \mathrm{c}, 1 \mathrm{~d}$, were inserted by mistake and are duplicates of Tables $2-4$. The copy editors are sorry for this occurrence.

The online version of the original article can be found at http://dx.doi.org/10.1007/s00445-004-0377-3

C. B. Lewis-Kenedi · R. A. Lange $(\square) \cdot$ C. M. Hall

Department of Geological Sciences, University of Michigan,

Ann Arbor, MI 48109-1063, USA

e-mail: becky@umich.edu

Tel.:+1-734-7647421

Fax: +1-734-7634690

H. Delgado-Granados Instituto de Geofísica, UNAM, 04510 DF Coyoacan, Mexico 